\title{
FARMERS PARTICIPATION IN AGRO-TOURISM DEVELOPMENT AT SUBAK JATILUWIH, PENEBEL DISTRICT, TABANAN REGENCY
}

\author{
Putu Fajar Kartika Lestari*, Ni Putu Sukanteri, Ni Putu Anglila Amaral \\ Agribusiness Study Program, Faculty of Agriculture and Business, Mahasaraswati University Denpasar \\ * Corresponding author. e-mail: pfajarkartika@unmas.ac.id
}

\begin{abstract}
The development of subak as a tourist attraction will be in line with the development of Balinese cultural tourism, considering that both are developed based on Balinese culture. This is an effort to maintain the sustainability of subak while controlling the conversion of paddy fields and supporting environmental sustainability. Today's tourists prefer to see beautiful scenery. Agrotourism is one type of tourism that utilizes agricultural business as a tourist attraction. One of the efforts made to continue to develop tourism but still maintain the existence of subak itself is to combine these two things into a new tourist attraction. The attraction that can be developed by combining tourism with agriculture is through the concept of agrotourism. Agrotourism is a tourism development that offers farmer activities in the fields as a tourist attraction. Not only the activities, but the use of agricultural products can also be used as agro-tourism-based tourism products. This research was conducted with the following objectives (1) How is the participation offarmers in the development of agro-tourism and (2) the factors that influence the participation of farmers on the development of agro-tourism. This research was conducted in Subak Jatiluwih, Penebel District, Tabanan Regency. The location of this research was determined purposively on the basis of the consideration that Jatiluwih Subak is one of the subaks targeted for agro-tourism development. The number of samples in Subak Jatiluwih is 199 people. The data analysis method used of Likert scale and multiple linear regression. Participation in Planning score $80.2 \%$, Participation in Implementation score 73.9\%, Participation in Utilization score $73.5 \%$, and Farmers Participation in Evaluating score 65\%. The highest farmer participation is in the $80.2 \%$ agro-tourism development planning.
\end{abstract}

Keywords: Agro-tourism, development, participation

\section{Introduction}

Indonesia, which is famous for its tourist attractions around the world, is the island of Bali. Bali is famous for the charm of natural and cultural tourism which is very beautiful and interesting. The Island of the Gods is the nickname of Bali which has succeeded in proving its ability to combine tourism and culture as a heritage that is recognized in the eyes of the world [1,2,3]. This is evidenced by the ratification of Subak in Bali (Bali Culture Landscape) as a World Heritage site by the United Nations (UN) Agency [4]. Subak is a community organization that specifically regulates the irrigation system used for rice cultivation in Bali. Subak usually has a temple called Pura Bedugul. The Subak Temple was specially built by farmers and dedicated to the worship of Dewi Sri as a symbol of the goddess of prosperity or fertility. Subak as an 
irrigation system is a commensurate technology that has been integrated with the socio-cultural of the local community $[5,6,7]$. The technological equivalence of the subak system was demonstrated by the members of the subak through an understanding of how to use irrigation water based on the Tri Hita Karana (THK) which is integrated by making buildings and physical networks.

Irigation, how to operate, coordinating the implementation of operations and maintenance carried out by Pekaseh (head of Subak), institutional forms, and information for their management $[8,9,10]$. With that in mind, the subak system is able to anticipate possible water shortages by managing the implementation of cropping patterns. Furthermore, the subak system as a commensurate technology, basically has the opportunity to transform, as long as its technological equivalence values are met. The weakness lies in the inability of the defense system to withstand intervention from outsiders. In maintaining subak defenses to be more awake and preventing land conversion which cau ses the extinction of the subak system, the subak water system really needs to be preserved and developed for the better $[11,12]$.

One way that can be used to maintain and develop the Subak system is to make it a cultural-based tourism object and has high economic value. Besides being able to maintain subak, this method can also provide an increase in income for farmers, so that sustainable agriculture can be created. Agrotourism is one way to provide high economic value into the subak system. Subak as a cultural-based tourist attraction that will be visited by tourists. Today's tourists prefer to see beautiful scenery. Agrotourism is one type of tourism that utilizes agricultural businesses to become a tourist attraction $[13,14,15]$. One of the efforts made to continue to develop tourism but still maintain the existence of subak itself is to combine these two things into a new tourist attraction. The attraction that can be developed by combining tourism with agriculture is through the concept of agrotourism [16,17] (Putri et al; 2020; Kusuma et al.,2018;). Agrotourism is a tourism development that offers farmer activities in the fields as a tourist attraction. Not only the activities, but the use of agricultural products can also be used as agro-tourism-based tourism products $[18,19]$. This research was conducted with the following objectives: (1) How is the participation of farmers in the development of agro-tourism? (2) the factors that influence the participation of farmers on the development of agro-tourism?

\section{Materials and Methods}

This research was conducted in Subak Jatiluwih, Penebel District, Tabanan Regency. The location of this research was determined purposively on the basis of the consideration that Jatiluwih Subak is one of the subaks targeted for agro-tourism development. The number of members of Subak Jatiluwih in 2017 was 537 people, spread over six tempek namely (1) Tempek Uma Kayu as many as 47 members, (2) Tempek Peace as many as 51 members, (3) Tempek Gunung Sari as many as 110 members, (4) Tempek Besikalung as many as 95 members, (5) Tempek Telabah Gede as many as 193 members, (6) Tempek Uma Duwi as many as 57 members and Tempek Kesambi as many as 37 members. Determination of the number of samples taken, carried out by Slovin theory. While the determination of the number of samples to determine tempek using proportional random sampling technique, taking into account the number of farmers of each tempek is different. Determination of the number of samples taken, carried out by Slovin theory [20,21,22]. While the determination of the number of samples to determine tempek using proportional random sampling technique, taking into account the number of farmers of each tempek is different. Slovin's formula is as follows. 


$$
\begin{aligned}
& \mathrm{N}=\frac{\mathrm{N}}{\left(1+N e^{2}\right)} \\
& =\frac{537}{[1+(537 \times 0.5)]} \\
& =\frac{537}{2.7} \\
& =198.88 \text { rounded up to } 199
\end{aligned}
$$

Information:

$\mathrm{n}=$ Number of samples

$\mathrm{N}=$ Total Population

$\mathrm{e}=$ Level of accuracy $(5 \%)$

Determine the sample in the cluster or tempek using the sampling fraction formula per cluster. (Sugiyono, 2004) with the following formula.

$$
\mathrm{fi}=\frac{\mathrm{Ni}}{\mathrm{N}}
$$

then get the sample size per cluster

Information :

$$
\text { ni }=\text { fi } \times \text { n }
$$

$\mathrm{fi}=$ sampling fraction cluster (number of tempek population)

$\mathrm{Ni}=$ number of individuals in the cluster (number of tempek samples)

$\mathrm{N}=$ total population

$\mathrm{n}=$ number of members included in the tempek sample

$\mathrm{ni}=$ the number of members included in the sub sample

Based on the number of samples that have been determined as above, the distribution of the number of samples in each tempek is as shown in Table 2.1.

Table 2.1

Population and Sample Distribution

\begin{tabular}{cccc}
\hline No & Name Tempek & Population (person) & Sample (person) \\
\hline 1 & Uma Kayu & 47 & 17 \\
2 & Kedamaian & 51 & 19 \\
3 & Gunung Sari & 110 & 41 \\
4 & Besi Kalung & 95 & 35 \\
5 & Telabah Gede & 140 & 52 \\
6 & Uma Duwi & 57 & 21 \\
7 & Kesambi & 37 & 14 \\
& Jumlah & 537 & 199 \\
\hline
\end{tabular}

Source: Jatiluwih Subak Data, 2017 
The total number of samples is 199 people. The distribution of the most samples lies in Tempek Telabah Gede, which is 52 people, and the least number of samples lies in Tempek Kesambi, which is 14 people. The method of data analysis in this study to answer the first problem is to use a Likert scale. The Likert scale is used to measure attitudes, opinions, and perceptions of a person or group of people about social phenomena [23,24]. Farmer participation is measured by using four indicators seen from the level of farmer participation in the development of agro-tourism for, among others:
1. Planning
2. Utilization
3. Implementation
4. Evaluation

The indicator measurement to measure the level of farmer participation uses the Likert method, which describes the five indicators into several question items that have been arranged in a questionnaire and each question item is given a score according to the respondent's choice. a psychometric scale that is commonly used in questionnaires and states the most widely used scale for research in the form of surveys. Determination of categories regarding farmer participation in food security programs is determined by the formula:

$$
\begin{gathered}
=\frac{\begin{array}{c}
\text { Interval } \\
\text { highest score } \% \text { minus lowest score } \%
\end{array}}{\text { number of classes }} \\
\text { Interval }=\frac{100 \%-20 \%}{5}=16
\end{gathered}
$$

Based on the above formula for the class interval, the participation category for agro-tourism development will be obtained as follows:

a.Very low category if the score is $>20$ to $36 \%$

b.Low category if the score is $>36 \%$ to $52 \%$

c. Medium category if the value is $>52 \%$ to $68 \%$

d.High category if the score is $>68 \%$ to $84 \%$

e.Very high category if the score is $>84 \%$ to $100 \%$.

To find out the factors that influence farmer participation in the agro-tourism development program, multiple linear regression analysis was carried out [25]. The form of the multiple linear function used is

$$
\begin{array}{crl}
Y= & \beta_{0}+\beta_{1} X_{1} & +\beta_{2} X_{2}+\beta_{3} X_{3}+\beta_{4} X_{4} \\
X_{1} & : & \text { Age of farmer (years) } \\
X_{2} & : & \text { Formal education (years) } \\
X_{3} & : & \text { Number of family members (person) } \\
X_{4} & : & \text { Cultivated land area (are) } \\
Y & : & \text { Farmer participation (\%) } \\
\beta 0 & : & \text { Constant } \\
\beta i & : & \text { Regression coefficient }
\end{array}
$$

With the output of the regression coefficient obtained, the feasibility is then tested with the F-test, $\mathrm{t}$-test and the coefficient of multiple determination $\mathrm{R}^{2}$. 


\section{Results and Discussion}

\subsection{Farmer Participation in Agrotourism Development}

The results of descriptive analysis on farmer participation in agro-tourism development in Subak Jatiluwih, Penebel District, Tabanan Regency include participation in planning, participation in implementation, participation in utilization, participation in assessment (evaluation).

a. Participation in Planning

The participation of farmers in agro-tourism development planning in Subak Jatiluwih, Penebel District, Tabanan Regency, it can be seen that most (65\%) respondents are in the category of very high participation in planning agro-tourism development. The highest planning is mainly on the aspect / dimension of activity in planning agro-tourism development activities, and the lowest is on the active aspect in providing education about the application of technology to assist the process of agro-tourism development activities. The average score in agro-tourism planning of 199 respondent farmers is $80.2 \%$. So overall, the participation of respondent farmers in agro-tourism development planning in Subak Jatiluwih, Penebel District, Tabanan Regency is still in the High category.

b. Participation in Implementation

The participation of farmers in the implementation of agro-tourism development in Subak Jatiluwih, Penebel District, Tabanan Regency can be seen that most (48.6\%) respondents are in the category of high participation in implementing agro-tourism development. The highest program implementation, especially in the aspect/dimension of activeness in rice cultivation in accordance with awig-awig in Subak Jatiluwih, and the lowest is on the aspect of farmer intensity in financing the agro-tourism development program business. The average score in implementing food security from 199 respondent farmers is $73.9 \%$. So overall the participation of respondent farmers in the implementation of agro-tourism development in Subak Jatiluwih, Penebel District, Tabanan Regency is still in the high category.

\section{c. Participation in Utilization}

The participation of farmers in the use of agro-tourism development in Subak Jatiluwih, Penebel District, Tabanan Regency, it can be seen that most (54.3\%) respondents are in the category of high participation in utilizing agro-tourism development in Subak Jatiluwih, Penebel District, Tabanan Regency. The highest utilization of agro-tourism development programs is mainly on the aspect/dimension of the intensity of farmers in utilizing their land for agro-tourism development, and the lowest is on the aspect of farmers' contribution in subsidizing their capital to improve agro-tourism development. The average score in the use of food security programs from 199 respondent farmers is $73.5 \%$. So overall, the participation of respondent farmers in utilizing agro-tourism development in Subak Jatiluwih, Penebel District, Tabanan Regency is still in the high category.

\section{d. Farmers Participation in Evaluating}

The participation of farmers in evaluating agro-tourism development in Subak Jatiluwih, Penebel District, Tabanan Regency, it can be seen that most (65.7\%) farmers are in the category of moderate participation in evaluating agro-tourism development in Subak Jatiluwih. The highest program evaluation was mainly on the aspect/dimension of farmer activity in monitoring agro-tourism development activities, and the lowest was on the active aspect of farmers in providing input on program improvement. The average score in the use of agro-tourism development from 199 respondent farmers is 65\%. So overall the participation of respondent farmers in evaluating the development of agro-tourism in Subak Jatiluwih, Penebel District; Tabanan Regency is still in the medium category. 


\subsection{Factors Influencing Farmers' Participation in Agro-tourism Development}

The results of the analysis of variance from the regression function of the influence of respondents' characteristics indicate that the influence of factors such as farmer age (X1), formal education (X2), number of family members (X3) and arable land area (X4) are jointly very significant on their participation in agrotourism development ( $\mathrm{Y}$ ), which is indicated by the F value equal to 9.607 with a significance of 0.000 , In addition, judging by the results of the estimation of the respondent's characteristic function model, it is shown that the correlation value with all independent factors of farmer characteristics on farmer participation in agro-tourism development or $\mathrm{R}=0.749$ and $\mathrm{R}$-square of 0.562 which is quite high $[3,11]$.

The estimation of the influence of the respondent's farmer characteristics on their participation in agro-tourism development can be explained by the respondent's characteristic factors that have an insignificant effect (sig. > 0.05), namely the age of the farmer and the formal education of the farmer, while the significant influence of the respondent (sig < 0.05) is number of family members and land area [11]. Farmer age has no significant effect on farmer participation in agro-tourism development. This is said to be insignificant because the significant level of farmer age is $0.379>0.05$. This shows that there is no tendency that older farmers have higher participation in agro-tourism development or vice versa. This fact means that there is no tendency for younger or older farmers to be more interested in participating in agro-tourism development [4].

Farmers' formal education has no significant effect on farmer participation in agro-tourism development. This is said to be insignificant because the significant level of formal education of farmers is $0.173>0.05$. This shows that there is no tendency for farmers with higher education to have higher participation than farmers with lower education or vice versa. This may be due to farmers' understanding of the benefits of food security programs as well as their ability to participate equally in every level of formal education they have.

The number of family members has a very significant influence on the participation of farmers in the development of agro-tourism. This is said to be significant because the significant level of the number of family members is $0.009<0.05$. This shows that there is a tendency for farmers who have a larger number of family members to have a higher participation in the development of agro-tourism. With a large number of family members, it can increase the mobilization of energy in managing food security programs.

The size of the arable land of the farmers has a significant influence on their participation in the development of agro-tourism. This is said to be significant because the significant level of arable land area is $0.039<0.05$. This indicates that there is a tendency for respondents who have a higher arable area to have a higher participation in agro-tourism development. With a high arable land area, it can increase the enthusiasm and motivation of farmers in developing agro-tourism

\subsection{Conclusion}

\section{Conclusion}

1. Farmer participation in agro-tourism development planning of 199 farmer respondents was $80.2 \%$. So the overall participation of respondent farmers in agro-tourism development planning in Subak Jatiluwih is still in the High category.

2. Participation of farmers in the implementation of agro-tourism development of 199 farmer respondents was $73.9 \%$. So the overall participation of respondent farmers in the implementation of agro-tourism development in Subak Jatiluwih is still in the high category.

3. The participation of farmers in the use of agro-tourism development of 199 respondent farmers is $73.5 \%$. So overall, the participation of respondent farmers in utilizing agro-tourism development in Subak Jatiluwih is still in the high category. 
4. Participation of farmers in the use of agro-tourism development of 199 respondent farmers is $65 \%$.So overall the participation of respondent farmers in evaluating agro-tourism development programs in Subak Jatiluwih is still in the moderate category.

5. The number of family members and the area of land cultivated by farmers have a very real influence on their participation in the development of agro-tourism. The higher the number of family members and the area of land cultivated by farmers, the higher the participation in the development of agro- tourism.

\subsection{Suggestions}

1. Farmer participation in evaluating agro-tourism development needs to be increased through learning and knowledge of farmers on agro-tourism

2. The development of Subak Jatiluwih must be accompanied by the provision of adequate tourist facilities for visitors. This in turn can encourage the empowerment of subak farmers through the provision of additional sources of income from tourism activities in addition to income from farming. In essence, all development strategies for Subak Jatiluwih must be in line with the rules and philosophy of subak so that it does not threaten the sustainability of subak and is able to empower subak to become sustainable subak, not vice versa, Jatiluwih subak is only an object of business exploitation that only benefits outsiders.

\section{References}

[1] Sumiyati; Sutiarso,L.; Windia, W; \& Sudira, P (2011). Evaluasi Kinerja Fisik Sistem Subak Yang berorientasi Agroekowisata Menggunakan Pendekatan Logika Fuzzy. Jurnal Teknik Industri, Vol. 12, No. 2, Agustus 2011: 147-155.

[2] Rohman, A.F; Sarjana, I.D.G.R; \& Anggreni, I.G.A.A. Pemanfaatan Inovasi Burung Hantu (Tyto Alba) sebagai Pengendali Hama Tikus (Rattus Argentiventer) oleh Anggota Subak di Desa Senganan Kecamatan Penebel Kabupaten Tabanan. Jurnal Agribisnis dan Agrowisata. ISSN: 2685-3809 Vol.9, No.1, Januari 2020.

[3] Jaya, A.S; Windia, I.W; \& Parining, N. (2017). Dampak Program Simantri 245 Banteng Rene terhadap Subak Renon di Kecamatan Denpasar Selatan, Denpasar. E-Jurnal Agribisnis dan Agrowisata. ISSN: 2301-6523 Vol. 6, No. 2, April 2017.

[4] Sari, D.A.T; Putra, I.G.S.A; \& Suardi, I.D.P.O (2017). Perilaku Petani Pada Program Pengembangan Klaster Padi Binaan Bank Indonesia (Kasus Subak Pulagan, Desa Tampaksiring, Kecamatan Tampaksiring, Kabupaten Gianyar). E-Jurnal Agribisnis dan Agrowisata. ISSN: 2301-6523 Vol. 6, No. 1, Januari 2017.

[5] Windia, W. \& Wiguna, W.A.A, (2013). World Cultural Heritage Subak. Denpasar: Udayana University Press.

[6] Diarta, I.K.S \& Sarjana, I.M (2018). Strategi Pengembangan Subak Padanggalak Sebagai Daya Tarik Wisata di Kota Denpasar Bali (Subak Padanggalak Development Strategy as Tourism Attraction in Denpasar City Bali). Media Konservasi Vol. 23 No. 3 Desember 2018: 281-292.

[7] Martha. I.M.A.W; Diarta, I.K.S; \& Putra, I.G.S (2020). Dampak Alih Fungsi Lahan Pertanian ke Non Pertanian Terhadap Tingkatan Konflik dan Manajemen Konflik di Subak Bau Kabupaten Gianyar. Jurnal Agribisnis dan Agrowisata. ISSN: 2685-3809 Vol. 9 No.1, Januari 2020.

[8] Windia, W\& Dewi, R K. (2011). Business Analysis Based on Tri Hita Karana. Denpasar: Udayana University Press.

[9] Wiraraja, G.J; Windia, I.W; \& Sudarta, I.W (2016). Dampak Alih Fungsi Lahan Sawah Petani Pemilik terhadap Kehidupan Rumah Tangganya (Studi Kasus di Subak Lange, di Kawasan Desa Pemecutan Kelod, Kecamatan Denpasar Barat). E-Jurnal Agribisnis dan Agrowisata. ISSN: 2301-6523 Vol. 5, No. 2, April 2016. 
[10] Niswatin; \& Mahdalena (2016). Nilai kearifan lokal "Subak" sebagai modal sosial transmigran etnis Bali. Jurnal Akuntansi Multiparadigma JAMAL. Volume 7 Nomor 2 Halaman 156-323 Malang, Agustus $2016 \quad$ ISSN 2086-7603 e-ISSN 20895879http://dx.doi.org/10.18202/jamal.2016.08.7015.

[11] Budhiarti, K.A.R; Windia, W; \& Astiti, N.W.S (2016). Strategi Pengembangan Subak Menjadi Lembaga Berorientasi Agribisnis di Kabupaten Badung (Kasus Subak Sengempel, Desa Bongkasa, Kecamatan Abiansemal). E-Jurnal Agribisnis dan Agrowisata. ISSN: 2301-6523 Vol. 5, No. 4, Oktober 2016.

[12] Sedana, G. (2019). Sustaining Traditional Irrigation System through Ecotourism Development: Case of Subak of Sembung, Denpasar, Bali, Indonesia. Proceedings of the International Conference on Industrial Engineering and Operations Management Toronto, Canada, October 23-25, 2019.

[13] Sutjipta, W. (2008). Half-Hearted Agribusiness Development. Udayana University. Denpasar

[14] Dewi, N.W.A.K; Sarjana.I.P; Wibawa, I.P.S (2020). Pelestarian Subak Sembung Melalui Pendekatan Hukum Tradisional Di Desa Peguyangan Kaje. Jurnal Hukum dan Kebudayaan Fakultas Hukum Universitas Hindu Indonesia Denpasar Volume 1, Nomor 2 November 2020 ISSN: 2722-3817 https://ejournal.unhi.ac.id/index.php/hkb pp. 12-20.

[15] Norken, I.N (2019). Efforts to preserve the sustainability of subak irrigation system in Denpasar city, Bali Province, Indonesia. MATEC Web of Conferences 276. https://doi.org/10.1051/matecconf /201927604002.

[16] Putri, N.L.M.A.Y; Suryawardani, I.G.A.O; \& Diarta. I.K.S (2020). Strategi Perekayasaan Subak Sembung sebagai Daya Tarik Wisata di Perkotaan. Jurnal Agribisnis dan Agrowisata. ISSN: 2685-3809 Vol. 9 No. 1, Januari 2020.

[17] Kusuma, I.G.P.S; Windia, I.W; \& Astiti, N.W.S (2018). Peran Modal Sosial dalam Melestarikan Subak Bukti Batan Badung di Desa Gulingan Kecamatan Mengwi Kabupaten Badung. E-Jurnal Agribisnis dan Agrowisata. ISSN: 2301-6523 Vol. 7, No. 3, Juli 2018.

[18] Mataliana, G.N.A; Yudhari, I.D.A.S; \& Dewi, I.A.L (2015). Keragaan Usahatani Pandan Wangi (Pandanus amaryllifolius roxb) di Subak Tegenungan Desa Kemenuh Kecamatan Sukawati Kabupaten Gianyar. E-Jurnal Agribisnis dan Agrowisata. ISSN: 2301-6523 Vol. 4, No. 1, Januari 2015

[19] Dyatmikawati, P. (2017). Function of Customary Law in Managing Water Management Within Farmers Organizatin: Case of Subak Kedua, Denpasar City, Bali Province, Indonesia. Jurnal Pendidikan IPS Indonesia is licensed under A Creative Commons Attribution-Non Commercial 4.0 International License.

[20] Suputra, D.P.A; Ambarawati, I.G.A.A; \& Tenaya, I.M.N (2012). Faktor-Faktor yang Mempengaruhi Alih Fungsi Lahan Studi Kasus di Subak Daksina, Desa Tibubeneng, Kecamatan Kuta Utara, Kabupaten Badung. E-Journal Agribisnis dan Agrowisata. ISSN: 2301-6523 Vol. 1, No. 1, Juli 2012.

[21] Lestari, N.P.N.E (2020). Penyuluhan tentang potensi subak dalam mendukung pengembangan desa pinge sebagai desa wisata berbasis masyarakat parta. Jurnal Pengabdian Kepada Masyarakat http://journal.undiknas.ac.id/index.php/parta Volume 1 Nomor 1 Juni 2020.

[22] Permana, Y.S (2016). Mampukah subak bertahan? studi kasus ketahanan sosial komunitas subak pulagan, gianyar, bali. Masyarakat Indonesia, Vol. 42 No.2, Desember 2016.

[23] Sugiyono 2014. Research methods quantitative, qualitative and R and D. Bandung: alphabeta.

[24] Lanya; Dibia,I.N; Diara.,I.D \& Suarjaya, D.N (2017). Analysis of Subak Landuse Change Due to Tourism Accomodation Development in North Kuta Sub-district, Badung Regency, Indonesia. The 5th Geoinformation Science Symposium 2017 (GSS 2017) IOP Publishing IOP Conf. Series: Earth and Environmental Science 98 (2017) 012024 doi :10.1088/1755-1315/98/1/012024. 
[25] Paramartha, I.G.N.D \& Dewi, N.A.N (2012). Perancangan Sistem Informasi Untuk Media Promosi Agrowisata Pertanian Subak. E-Journal Agribisnis dan Agrowisata. ISSN: 2301-6523 Vol. 1, No. 1, Juli 2012. 